UCRL-ID-129785

\title{
Isotope Tracers of Organic Carbon During Artificial Recharge
}

\author{
M. Lee Davisson
}

February 9, 1998

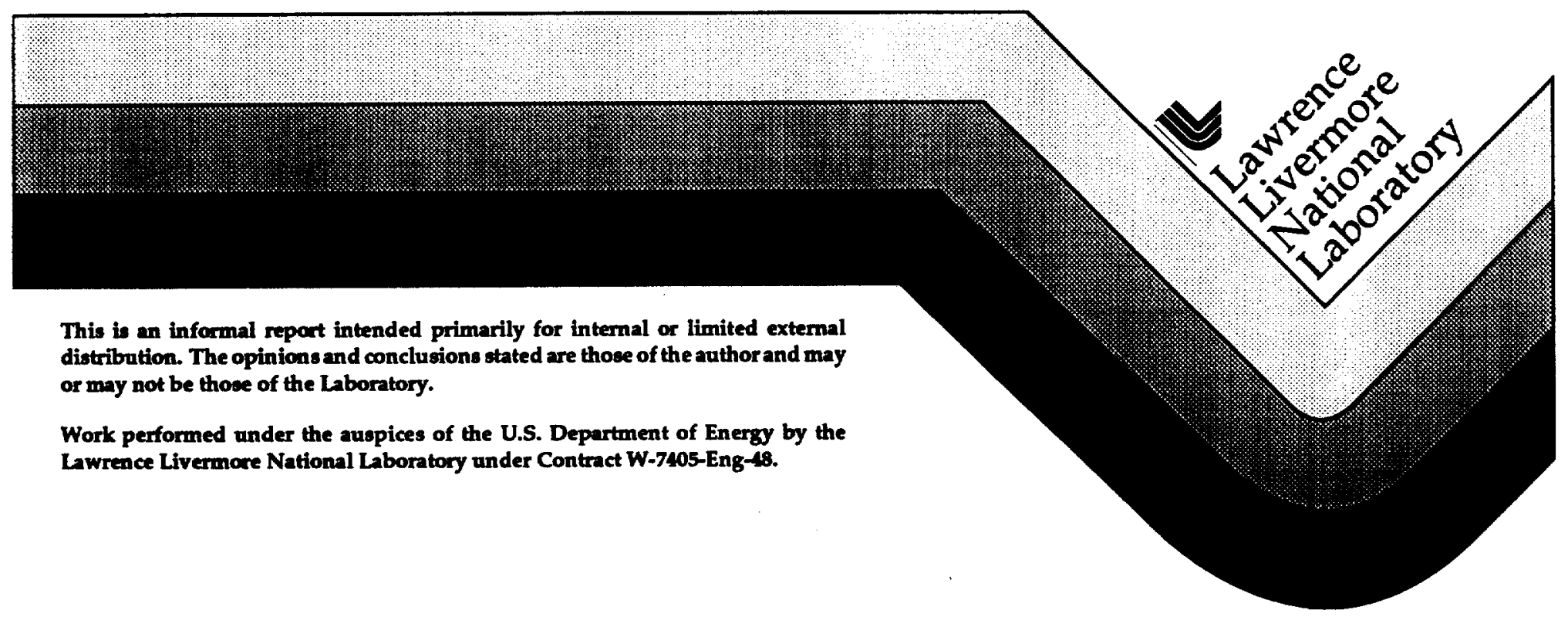




\section{DISCLAIMER}

This document was prepared as an account of work sponsored by an agency of the United States Government. Neither the United States Government nor the University of California nor any of their employees, makes any warranty, express or implied, or assumes any legal liability or responsibility for the accuracy, completeness, or usefulness of any information, apparatus, product, or process disclosed, or represents that its use would not infringe privately owned rights. Reference herein to any specific commercial product, process, or service by trade name, trademark, manufacturer, or otherwise, does not necessarily constitute or imply its endorsement, recommendation, or favoring by the United States Government or the University of California. The views and opinions of authors expressed herein do not necessarily state or reflect those of the United States Government or the University of California, and shall not be used for advertising or product endorsement purposes.

This report has been reproduced directly from the best available copy.

Available to DOE and DOE contractors from the Office of Scientific and Technical Information

P.O. Box 62, Oak Ridge, TN 37831

Prices available from (615) 576-8401, FTS 626-8401

Available to the public from the

National Technical Information Service

U.S. Department of Commerce

5285 Port Royal Rd.,

Springfield, VA 22161 


\title{
Isotope Tracers of Organic Carbon During Artificial Recharge
}

\author{
M. Lee Davisson \\ Isotope Sciences Division
}

\section{BACKGROUND}

About 5 to $10 \%$ of carbon in natural water occurs in organic forms. The combined total of these forms is known as total organic carbon (TOC), which is a regulated water quality parameter. TOC varies from around 1 to $10 \mathrm{mg} / \mathrm{L}$ as carbon in surface waters. Groundwater typically has less than $1 \mathrm{mg} / \mathrm{L}$ TOC, although groundwater residing in sediments with high organic content has more. Humic substances comprise up to half the TOC and are thought to be polymeric molecules formed from condensation reactions of plant lignin, polysaccharides, and/or proteins, although direct determinations of molecular forms have been illusive. These substances are most commonly observed in groundwater (Thurman, 1985a; Thurman, 1985b). Non-humic substances are typically lower molecular weight and simpler compounds derived from various sources.

This project developed an analytical technique for measuring the isotopic abundance of ${ }^{14} \mathrm{C}$ and ${ }^{13} \mathrm{C}$ in TOC in order to test whether these measurements can trace TOC interaction with sedimentary organic matter (SOM). SOM is detritus incorporated in sedimentary material at the bottom of rivers and lakes, soils, and subsurface aquifer rocks. The carbon in SOM has a lower ${ }^{14} \mathrm{C}$ concentration than the carbon in surface water TOC. Their interaction during surface water recharge would be reflected in decreased ${ }^{14} \mathrm{C}$ concentrations. One previous study measured ${ }^{14} \mathrm{C}$ and ${ }^{13} \mathrm{C}$ of TOC in surface water and groundwater (Schiff et al., 1997), but did not address issues of SOM exchange. Other work has measured organic ${ }^{14} \mathrm{C}$ in shallow groundwater recharge (Wassenaar et al., 1992; Geyer et al., 1993; Artinger et al., 1996), but in these studies they only measured ${ }^{14} \mathrm{C}$ on the dissolved humic substances in order to determine the water's age. These workers suggested that the low ${ }^{14} \mathrm{C}$ content observed in young recharge was due to exchange between humic substances and SOM of the soil. The extent of exchange depended on the SOM concentration, microbiological activity, and dissolved oxygen content of the water.

The ${ }^{14} \mathrm{C}$ may quantify the mass transfer of SOM into TOC during groundwater recharge, particularly when measured on a recharged surface water labeled with a conservative water tracer. These measurements could have direct bearing in California, where TOC has a proposed regulatory limit of $\sim 1 \mathrm{mg} / \mathrm{L}$ for recycled waste-water recharged into groundwater drinking supplies. This strict regulation is due to the uncertainty in the TOC composition and any potential toxicity. There is interest among regulators and water managers in determining whether the TOC in surface water is the same TOC found in groundwater after the water has been artificially recharged. If it can be shown that the TOC undergoes compositional changes during recharge, it could provide a basis to change current regulatory thinking, and thus possibly decrease the cost of producing this type of water for drinking water supplies. The goal in this feasibility study was to 1 ) use a conservative tracer to track surface water recharge and quantify 
changes in the TOC concentration, and 2) measure the natural abundance of ${ }^{13} \mathrm{C}$ and ${ }^{14} \mathrm{C}$ in the TOC as a means to quantify its interaction with SOM.

\section{EXPERIMENTAL AND RESULTS}

Figure 1 shows results from a conservative tracer study at Orange County, California. In this experiment, on October 1, 1996, Colorado River water was introduced into an abandoned gravel quarry, which is used by Orange County to recharge groundwater to meet drinking water demands. The ${ }^{18} \mathrm{O} /{ }^{16} \mathrm{O}$ ratio of Colorado River water is distinct from the ratio of local groundwater, which provided a means to trace the migration of the recharged water to a nearby monitoring well. The TOC content of the Colorado River water was measured before it was recharged, and then again after it had recharged and migrated to the monitoring well almost exactly one month later. It was found that, under nearly $100 \%$ saturated groundwater conditions, the TOC content decreased by a factor of two during recharge. Current regulatory thinking suggests that non-saturated groundwater conditions are necessary for this level of removal. This part of the experiment showed that isotopic measurements of ${ }^{18} \mathrm{O} /{ }^{16} \mathrm{O}$ ratios coupled with the TOC concentrations accurately quantify the amount of TOC removal in recharging groundwater. This approach is viable in any case where recharging groundwater is isotopically distinct.

On February 18, 1997, one liter samples of surface water in the gravel quarry were collected for isotopic analysis of the TOC. During this time, the water in the quarry was derived from nearby Santa Ana River. Samples were collected at the surface, at mid depth, and just above the bottom ( $\sim 50$ feet below surface). One month later on March $17^{\text {th }}$, groundwater was sampled at the same nearby monitoring. Based on the October recharge study using the $\mathrm{O}^{16} \mathrm{O}$ ratios, groundwater in the monitoring well should have been the same water in the gravel quarry one month earlier.

To prevent microbial interaction with the TOC, samples were poisoned immediately after sampling with 3-4 drops of a saturated solution of $\mathrm{HgCl}_{2}$ and refrigerated. After the samples were shipped to LLNL, they were split and one half filtered at $1.0 \mu \mathrm{m}$ and the other half at $0.2 \mu \mathrm{m}$. The groundwater sample was not filtered. The samples were then rotaevaporated to an $\sim 10 \mathrm{ml}$ volume. The samples were then acidified with $1 \mathrm{ml}$ of $6 \mathrm{M}$ $\mathrm{HCl}$ to remove inorganic carbon. The samples were then centrifuged, frozen, and freezedried. Freeze-dried weights were measured. Each freeze-dried sample was homogenized and a measured portion was loaded into a quartz tube with $\mathrm{CuO}$, evacuated and sealed, followed by combustion at $900^{\circ} \mathrm{C}$. Liberated $\mathrm{CO}_{2}$ after combustion was cryogenically purified and split. One split was measured for its ${ }^{13} \mathrm{C} /{ }^{12} \mathrm{C}$ ratio on a stable isotope ratio mass spectrometer and converted to a standard $\delta$ notation where $\delta=(\operatorname{Rs} / \operatorname{Rstd}-1) 1000$, Rs is the ${ }^{13} \mathrm{C}^{12} \mathrm{C}$ ratio of the sample, and Rstd is the ratio of a recognized standard. The other split was converted to graphite at $570^{\circ} \mathrm{C}$ in the presence of $\mathrm{H}_{2}$. The graphite was measured for its ${ }^{14} \mathrm{C}$ content at the Center for Accelerator Mass Spectrometry. Results are reported as percent of modern carbon (pmc), which is ${ }^{14} \mathrm{C} /{ }^{12} \mathrm{C}$ ratio of the sample normalized to the ratio of 1950 atmospheric $\mathrm{CO}_{2}$.

Figure 2 shows the results of the isotopic analyses and the TOC concentrations for each sample. The TOC concentration was calculated by the weight ratio of $\mathrm{CO}_{2}$ to the 
freeze-dried material. For the surface water samples, the ${ }^{14} \mathrm{C}$ of the TOC filtered at $1.0 \mu \mathrm{m}$ showed no significant variation with depth. However, ${ }^{14} \mathrm{C}$ of the $0.2 \mu \mathrm{m}$ filter size at the middle and bottom layers were significantly lower relative to the shallowest sample and the bigger filter size. For the groundwater sample, the ${ }^{14} \mathrm{C}$ of the TOC was lower than all the surface water analyses. The $\delta^{13} \mathrm{C}$ values of the TOC for the surface water samples had no significant difference, while the groundwater $\delta^{13} \mathrm{C}$ was only slightly lower. The calculated TOC concentrations for the surface water samples showed a significant increase with increasing depth for both filter size fractions. The groundwater sample TOC concentration was significantly lower than the surface water, similar to the TOC change observed during the October recharge experiment (see Fig. 1).

\section{DISCUSSION}

Based on the calculated TOC concentrations, organic carbon accumulated in the surface water from the surface toward the bottom of the gravel quarry (see Fig. 2). Humic substances are known to increase with depth in lakes, and have been proposed to originate either from iron oxide precipitation or anaerobic decomposition of particulate detritus (e.g. Steinberg and Muenster, 1985). The latter explanation is essentially the same as interaction with SOM. The TOC increase in the Orange County gravel quarry is associated with a ${ }^{14} \mathrm{C}$ decrease in only the $0.2 \mu \mathrm{m}$ filtered size, while the ${ }^{14} \mathrm{C}$ of the $1.0 \mu \mathrm{m}$ filtered samples remained the same, although both sizes increased in total concentration. The increase in the smaller size, however, is preferentially composed of older organic material, and this is consistent with formation of smaller molecules from decomposition of older SOM. However, this doesn't explain why the $1.0 \mu \mathrm{m}$ filter size also increased in concentration.

The ${ }^{14} \mathrm{C}$ concentration in the TOC of the groundwater is lower than any of the measured surface water samples. Assuming that this lower ${ }^{14} \mathrm{C}$ was entirely due to exchange with SOM, a mass transfer can be calculated. Unfortunately, the ${ }^{14} \mathrm{C}$ of the SOM was not determined. However, a lower limit of $25 \mathrm{pmc}$ is a reasonable estimate considering the depth of the monitoring well and the $<10,000$ year age of the sediments (R. Herndon, Orange County Water District, personal communication). Using the ${ }^{14} \mathrm{C}$ of the $0.2 \mu \mathrm{m}$ filter size at the bottom of the quarry $(101 \mathrm{pmc})$ as the beginning concentration, and $25 \mathrm{pmc}$ as the SOM concentration, then obtaining the $97 \mathrm{pmc}$ observed in the monitoring well would required only a 5 percent mass transfer of SOM into the TOC. Using the $1.0 \mu \mathrm{m}$ filter size as a beginning ${ }^{14} \mathrm{C}$ content, then a 9 percent mass transfer is required. A larger mass transfer would be required if the SOM were actually greater than 25 pmc.

Further work is required to better understand these data. In particular, ${ }^{14} \mathrm{C}$ measurements on the SOM are needed. However, it cannot be ruled out that the ${ }^{14} \mathrm{C}$ decrease of the TOC is simply caused by selective decomposition of younger carbon components of the TOC during recharge. In this case, more refractory parts of the TOC may be composed of older carbon. This question may be testable by measuring the ${ }^{14} \mathrm{C}$ of TOC and the humic substances separated from the TOC. Likewise, ${ }^{14} \mathrm{C}$ measurements on products of weak oxidation and other selective decomposition methods of the TOC may provide further information. In addition, ${ }^{14} \mathrm{C}$ measurements of groundwater up to one year old would indicate if ${ }^{14} \mathrm{C}$ continues to decrease beyond just the point of recharge. 


\section{REFERENCES}

Artinger, R., Buckau, G., Kim, J.I., and others, 1996, Influence of sedimentary organic matter on dissolved fulvic acids in groundwater. In Isotope in Water Resources Management, International Atomic Energy Agency, Vienna, 1995, pp. 57-72.

Geyer, S., Wolf, M., Wassenaar, L.I., and others, 1993, Isotope investigations on fractions of dissolved organic carbon for $14 \mathrm{C}$ groundwater dating. In Isotope Techniques in the Study of Past and Current Environmental Changes in the Hydrosphere and the Atmosphere, International Atomic Energy Agency, Vienna, 1993, pp. 359-380.

Schiff, SL; Aravena, R; Trumbore, SE; Hinton, MJ; and others., 1997, Export of DOC from forested catchments on the Precambrian Shield of Central Ontario: Clues from C13 and C-14. Biogeochemistry, 36, 43-65.

Steinberg, C., Muenster, U., 1985, Geochemistry and ecological role of humic substances in lakewater. In (Aiken, G.R., McKnight, D.M., Wershaw, R.L., eds) Himic Substances in Soil, Sediment, and Water. John Wiley and Sons New York, pp. 105146.

Thurman, E.M., 1985a, Organic Geochemistry of Natural Waters. Martinus Nijhoff/Dr W. Junk Publishers: Boston, 497 pp.

Thurman, E.M., 1985b, Humic substances in groundwater. In (Aiken, G.R., McKnight, D.M., Wershaw, R.L., eds) Himic Substances in Soil, Sediment, and Water. John Wiley and Sons New York, pp. 87-103.

Wassenaar, L.I., Aravena, R., Fritz, P., 1992, Radiocarbon contents of dissolved organic and inorganic carbon in shallow groundwater systems, implications for groundwater dating. In Isotope Techniques in Water Resources Development, International Atomic Energy Agency, Vienna, 1992, pp. 143-151. 


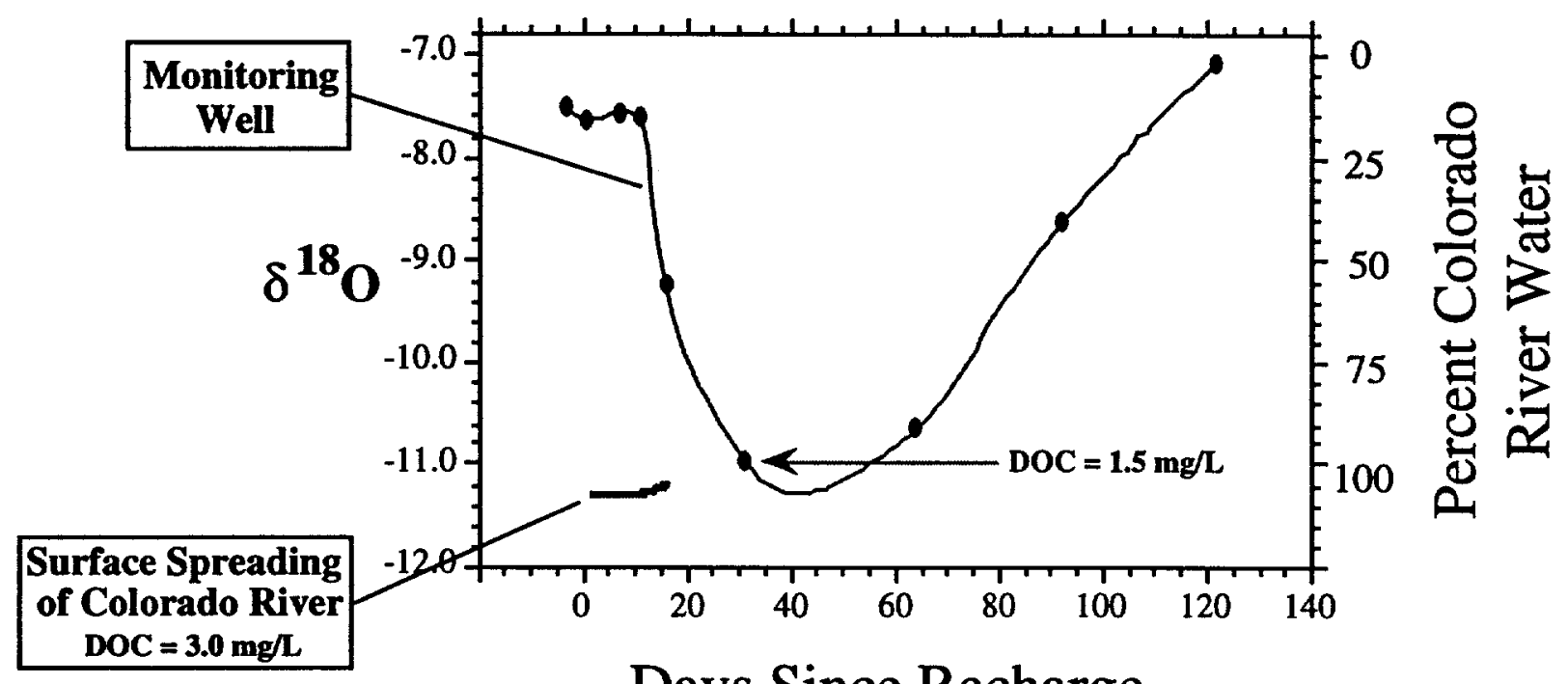

Days Since Recharge

Figure 1. Colorado River was used as a conservative tracer in an artificial recharge experiment in order to observe the changes in TOC concentration from surface water to a nearby monitoring well. About 30 days after recharging from the surface, TOC levels fell to $1.5 \mathrm{mg} / \mathrm{L}$, approaching the proposed regulatory limit of $1 \mathrm{mg} / \mathrm{L}$ for recycled waste-water influencing drinking water. 

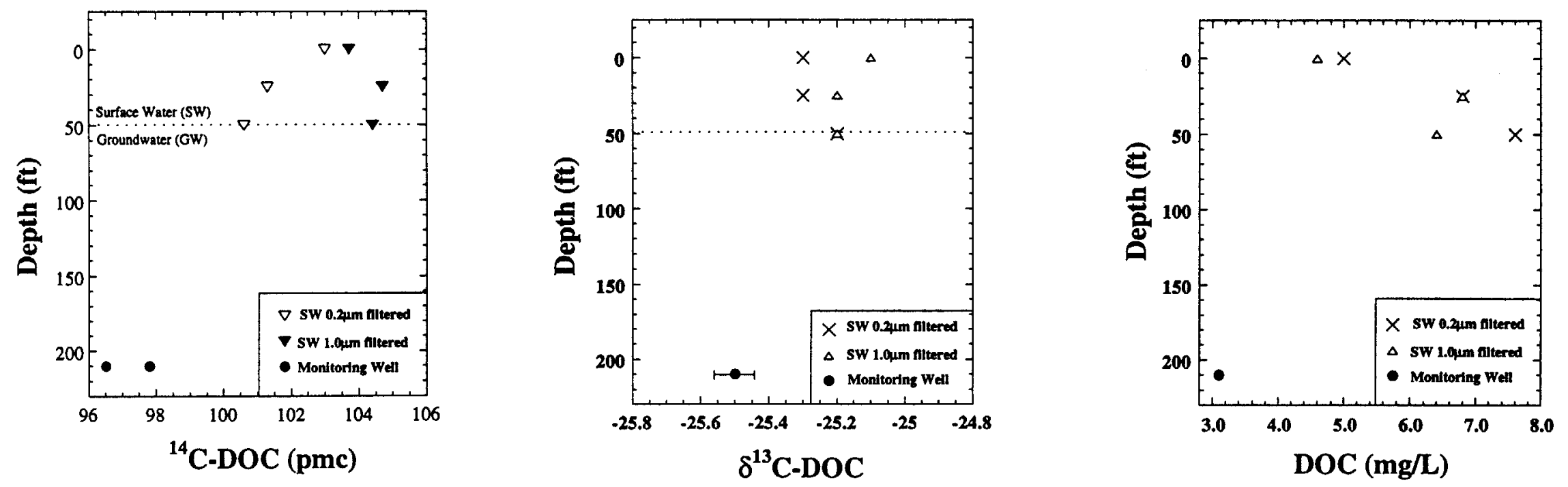

Figure 2. The decreasing ${ }^{14} \mathrm{C}$ content in surface water TOC filtered at $0.2 \mu \mathrm{m}$ and in groundwater TOC suggests exchange with SOM. The $\delta^{13} \mathrm{C}$ values only show a slight decrease between surface water and groundwater. The calculated TOC concentrations suggest an increase with depth in the lake water for both size fractions. The precision of analyses are $1 \mathrm{pmc}$ for the ${ }^{14} \mathrm{C}, 0.1$ per mil for the $\delta^{13} \mathrm{C}$, and $1 \mathrm{mg} / \mathrm{L}$ for the TOC. 


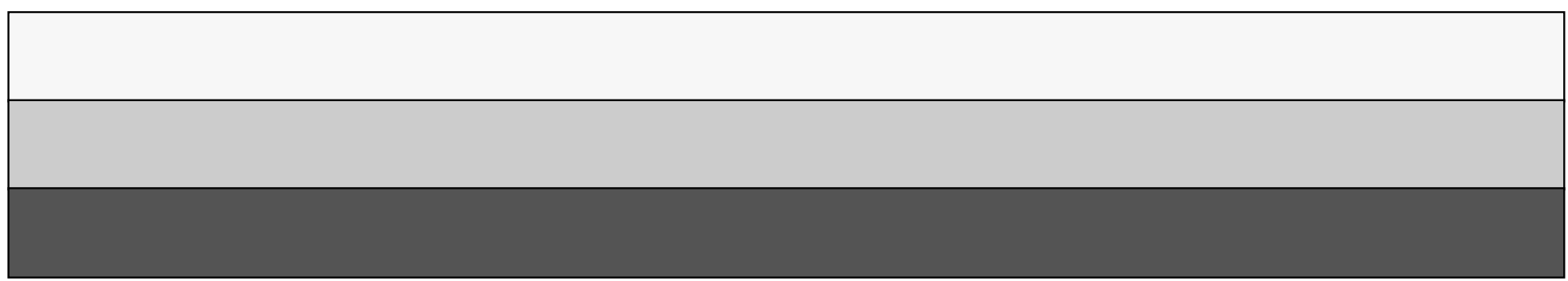

